A comparative analysis of the organic and conventional producer

\title{
A Comparative Analysis of the New Mexico Organic and Conventional Producer: Implications for Occupational Safety and Health Research and Practice
}

Carolyn A. Parshall, MPH, is an epidemiologist with the Albuquerque Area Southwest Tribal Epidemiology Center in New Mexico, USA

Francisco Soto Mas, MD, PhD, MPH, is a Professor of Public Health at the University of New Mexico College of Population Health, Albuquerque, New Mexico, USA

Fares Qeadan, $\mathrm{PhD}$, is an Assistant Professor in the Department Family \& Preventive Medicine, Division of Public Health at the University of Utah, USA

\section{Corresponding author}

Francisco Soto Mas

Associate Professor of Public Health

College of Population Health

MSC09 5070

1 University of New Mexico

Albuquerque, NM 87131-0001

USA

Telephone: 505-272-3011

Email: fsotomas@salud.unm.edu

\section{Disclosure Statement}

The authors declare that there are no conflicts of interest to disclose. No commercial or proprietary interest to declare.

\section{Acknowledgements}

The authors would like to thank Dr. William Athas and Dr. Kristine Tollestrup for serving as committee members for the oral defense of this study.

\section{Funding}

N/A 
A comparative analysis of the organic and conventional producer

\begin{abstract}
Research indicates that farmers' demographic characteristics and production practices have safety and health implications. However, current systems do not identify organic farmers independently from conventional farmers, and literature on how organic and conventional farmers compare is very limited. We conducted a secondary analysis of 2012 Census of Agriculture data to compare organic and non-organic farms and principal operators (POs) in New Mexico (NM). Organic farms were smaller in size, and POs of farms with organic sales were significantly younger (55.8 \pm 9.5 vs. $60.5 \pm 5.5$ years $)$ and less experienced (19.5 \pm 6.8 vs. 25.2 \pm 6.8 years). Significant differences were also found in POs ethnicity, race, and primary occupation. More farms with organic sales had a female PO compared to farms with non-organic sales (27\% vs. 19\%). Other significant differences related to work arrangements, household income, living conditions, and access to Internet. National surveys and regional studies may not accurately typify and describe the local organic producer, which is essential in order to advance policy, develop health interventions, and properly address occupational safety and risk among organic farmers. This study makes a unique contribution to understanding the importance of surveillance and collecting place-based data that are specific to the organic producer.
\end{abstract}

Key words: organic producer; organic practices; surveillance data; health and safety 
A comparative analysis of the organic and conventional producer

\section{Introduction}

Injury, illness, and fatality tracking systems do not identify organic farmers independently from conventional farmers and little is known about organic farmers and the factors that may contribute to occupational injury and illness. ${ }^{1,2}$ This gap in reporting must be addressed, as according to the National Institute for Occupational safety and Health (NIOSH), the fatality rate for crop production workers is one of the highest of any industry and every day approximately 100 agricultural workers suffer a lost-work-time injury. ${ }^{3}$ Similarly, according to the United States Department of Agriculture (USDA) the number of organic farms continues to grow globally. The latest official report indicates that there are more than 45,500 certified organic operations worldwide, with more than $62 \%$ located in the US. ${ }^{4}$

Differences in demographics and practices between organic and non-organic farmers have potential safety and health implications. For instance, demographics influence beliefs, perceptions, social relations and behaviors. Sex, age race, ethnicity, education, and income are related to behavior and biologic processes (e.g. mortality and morbidity), and are strong predictors of health outcomes. ${ }^{5}$ Data show that the general farming population in the US, mainly composed of white male producers, is decreasing in size and increasing in average age. ${ }^{6}$ In contracts, organic farming is increasing and the organic farmer is younger, more educated, and more diverse in terms of sex and racial composition. ${ }^{7}$ Regarding practices, a unique feature of organic farming is the no use of synthetic chemicals, which is a protective factor as exposure to synthetic pesticides and fertilizers constitutes an environmental hazard resulting in adverse health effects. ${ }^{8,9}$ Different level of risk between organic and conventional farming may also exist related to manual cultivation and harvesting. While a high majority of organic and conventional 
A comparative analysis of the organic and conventional producer

farms in the US are small (gross cash farm income under \$250,000) and common production practices such as the use of hand tools and small machinery may not differ between both groups, other factors should be considered. For instance, most organic farmers do not use any pesticides and rely more on manual practices (e.g. manual weeding) which increase physical risks for musculoskeletal conditions. These manual practices potentially increase time spent outdoors exposed to weather, dust, insects and other potential hazards. ${ }^{2}$

In summary, little is known about organic farmers and the potential risk for occupational injury and illness of organic agriculture. This is because current occupational surveillance systems have not kept up with the rapid increase in the number of organic farmers. Injury, illness, and fatality among organic farmers are not reported by any major tracking system, and most occupational health databases do not identify organic farmers independently from conventional farmers. ${ }^{1,2}$ Examples are the US Department of Labor (USDL) Injuries, Illnesses, and Fatalities (IIF) program and the National Agricultural Workers Survey (NAWS), which do not identify organic producers. IIF provides annual data by incident, industry, geography, occupation, and other characteristics through the Survey of Occupational Injuries and Illnesses (SOII) and the Census of Fatal Occupational Injuries; ${ }^{10}$ NAWS collects demographic, employment, and health data of crop workers. ${ }^{11}$ The Occupational Injury Surveillance of Production Agriculture (OISPA) survey, by the Centers for Disease Control and Prevention (CDC) and NIOSH, provides estimates for the number of occupational injuries to adults but does not identify organic farmers. ${ }^{12}$ These are existing surveillance systems that could seemingly integrate an "organic" category into their pre-existing data collection framework. A missed opportunity was the Farm Safety Survey (FSS), conducted in 2006 and 2011 by the USDA and the National 
A comparative analysis of the organic and conventional producer

Agricultural Statistics Service (NASS). It produced national estimates of specific injury and health hazards but did not categorized organic farmers. ${ }^{13}$

While there are reliable occupation data and extensive literature on agricultural workers, there is a lack of knowledge concerning occupational safety and health factors that may be unique to organic farmers. The purpose of this study was to address the gap in occupational surveillance data on organic farmers. Specifically, this study explored differences in demographics and production practices between organic and conventional principal operators (POs), and the potential implications for occupational safety and health and ultimately for health education and promotion.

\section{Methods}

This ecological study analyzed secondary, population-level data obtained from the USDA's 2012 National Census of Agriculture (COA). The 2012 COA is particularly relevant because it collected data on both organic and conventional farmers, including limited sociodemographic variables, using a unique tool. This allows for more reliable comparative studies. The COA is conducted every five years and in 2012 was mailed to 3,009,641 farms in the US that produced and sold, or normally would have sold, $\geq \$ 1,000$ of agricultural products during the census year. It had an $80 \%$ response rate and results were adjusted for under-coverage, nonresponse, and misclassification (14 USDA, 2012). ${ }^{14}$

\section{$\underline{\text { Population }}$}


A comparative analysis of the organic and conventional producer

This study focused on principal operators (POs) of NM farms. The population included both, conventional farms and farms with sales from certified or exempt organic crops and/or livestock. An "operator" may be the owner of the farm, a hired manager, tenant, renter, or sharecropper, and they may perform various tasks ranging from manual labor to office tasks.

\section{$\underline{\text { Data }}$}

PO characteristics and practices were manually extracted from the 2012 USDA COA's “Special Organics Tabulation" subject series report and entered into a Microsoft Excel spreadsheet. Data for variables were reported as averages, and their corresponding standard deviations were downloaded using the USDA QuickStats tool. A new category was created for "farms with no organic sales" by subtracting the number of "farms with any organic sales" from the number of “all farms." All data were reported as count data (number of farms), except for variables concerning age of PO, number of years on any operation, production expense per farm, and number of workers hired, all of which were reported as averages.

Tables 1-3 present all variables included for analysis. In general, variables were compared across the categories of "farms with any organic sales" and "farms with no organic sales." The only exception to this was the variable comparing average age of POs of "farms with any organic sales" to the average age of POs of "all farms," as well as the variable comparing "average years operating any farm" for POs of "farms with $>50 \%$ of total sales from organic sales" to "average years operating any farm" for POs of "all farms." This was because data reported for the variable “average age of PO" were reported as a calculated average for "farms with any organic sales" and "all farms." Due to the lack of raw data, it was not possible to re-calculate variables reported 
A comparative analysis of the organic and conventional producer

as averages to represent a category for "farms with no organic sales." However, based on the small percent of organic POs included in POs of all farms, we assumed that the average age for non-organic POs was approximately the same as that of POs of all farms, and average age was compared between POs of organic farms and POs of all farms, which includes organic farms.

Data on the variable "average years operating any farm" were also reported as a calculated average for POs of "farms with less than 50 percent of total sales from organic sales," "farms with 50 percent or more of total sales from organic sales," and "all farms." Again, due to the small percent of POs of farms with 50 percent or more of total sales from organic sales included in POs of all farms, we assumed that the average years operating any farm for non-organic POs were approximately the same as that of POs of all farms.

Data concerning average production expense per farm and number of workers hired for each farm were presented for "farms with less than 50 percent of total sales from organic sales," “farms with 50 percent or more of total sales from organic sales," and "all farms." In this case, raw data concerning number of farms and total production cost in dollars were provided for each farm category, making it possible to calculate the average production expense per farm for “farms with any organic sales," as well as "farms with no organic sales." Likewise, the number of farms that hired workers and the total number of workers hired were reported for farming categories, making it possible to calculate the average number of workers hired for "farms with any organic sales" as well as "farms with no organic sales." 
A comparative analysis of the organic and conventional producer

Variables were compared between "farms with any organic sales" and "farms with no organic sales" using two samples proportion z-tests computed in STATA 15.0 (StataCorp., 2017). Two samples independent t-test analyses were used to compare variables reported as averages in the 2012 USDA COA. The assumption of independence of samples was relaxed in order to perform the t-tests for average age of PO and average number of years on any operation. All analyses were performed at the $5 \%$ significance level.

\section{Results}

Table 1 presents 2012 USDA COA descriptive data on NM farms with organic and non-organic sales. Overall, organic farms represented less than $1 \%$ of all farms. Approximately half (53\%) of the farms were smaller than 10 acres, while less than a third (32\%) of those with non-organic sales were below the 10 acre threshold. Conversely, $5 \%$ of organic farms were 500 acres or larger, while $25 \%$ of farms with non-organic sales were at least 500 acres in size.

$<<$ Table 1 about here>>

POs of farms with organic sales were significantly younger $(55.8 \pm 9.5$ years $)$ than their nonorganic counterparts $(60.5 \pm 5.5)$ and less experienced (19.5 \pm 6.8 vs. $25.2 \pm 6.8$ years). Significant differences were also found in POs ethnicity, race, and primary occupation. Also, more farms with organic sales had a female PO compared to farms with non-organic sales (27\% vs. 19\%) (Table 2).

<<Table 2 about here>> 
A comparative analysis of the organic and conventional producer

Significant differences were found in production expenses and enrollment in crop insurance programs between farms with organic and non-organic sales. Additionally, the proportion of farms with organic sales that used conventional tillage practices was significantly higher than that of non-organic farms. Lastly, the proportion of farms that marketed products through CSA programs was significantly different between organic and non-organic farms (15\% vs. $0.7 \%$ ) (Table 3).

$<<$ Table 3 about here>>

Other significant differences between the POs of organic and non-organic farms related to work arrangements, household income, living conditions, and access to Internet. No significant differences were found between the proportion of organic and non-organic POs that indicated a total of 1-2 people living in their household (Tables 2, 3).

\section{Discussion}

The overall finding of this study is that in NM, there are significant differences between organic and non-organic farms and PO characteristics. This has relevant implications for occupational safety and health research, interventions, allocation of resources, and policy development.

Results indicate that more NM organic farms were small, had lower total sales, hired less workers and had more irrigated land than conventional farms (see Table 1). These differences should be considered when assessing occupational safety and risk, as workers in small business 
A comparative analysis of the organic and conventional producer

are exposed to higher health and safety risks compared to larger business, ${ }^{15}$ and have more difficulty assessing and controlling these risks. ${ }^{16}$ Furthermore, most occupational laws and regulatory agencies are designed for large businesses, leaving smaller ones unprotected in terms of reporting and enforcement. Similarly, small farms may have more economic pressures that influence the use of less-expensive production methods and equipment, possibly increasing injury risk. Small size may also mean more seasonal and labor-intensive work, more exposure to changing and extreme weather conditions, and more concentrated periods of work. All of these factors may lead to time pressures, stress, and fatigue, which are linked to increased risk of workplace incident and injury. Conversely, smaller farms may not use, or use less, heavy equipment and machinery which are known sources of fatality and injury among agriculture workers. $^{2,17}$

Regarding personal characteristics, POs of farms with organic sales were more educated, significantly younger, and less experienced compared to non-organic farms. Individual characteristics affect risk for injury, and studies have found that younger and less educated workers have an increased risk for injury. ${ }^{18}$ In addition, farmers $65+$ years of age have an increased risk of injury. This is in part due to functional limitations such as musculoskeletal disorders and hearing loss, and also to the use older machinery and not wearing protective gear when operating machinery and equipment. ${ }^{19}$

More organic farms had female operators compared to farms with non-organic sales. Women face unique agricultural health risks related to different physiology, gender norms, and biologic mechanisms. ${ }^{20}$ They may experience different ergonomic-related injuries than men due to 
A comparative analysis of the organic and conventional producer

differences in size and stature, and may have an increased risk of accidents involving machinery that has generally been designed to accommodate male physiques. Additionally, due to the gendered nature of agriculture work, women are less likely to receive valuable tacit knowledge concerning farming practices and safety, which is more commonly passed along to men. ${ }^{20}$ Research also suggests that male workers in traditionally male-dominated fields have more control over their work duties and often receive more safety training than do their female colleagues. ${ }^{21}$

Differences in production practices are relevant to risk assessment. For instance, a large proportion of farms with organic sales reported using conventional tillage practices, which may constitute an added risk as tillage usually requires the use of machinery and equipment, such as tractors -which are involved in the majority of workplace incidents and deaths occurring on farms. ${ }^{3}$ Finally, Internet access and marketing through CSA may also be relevant. Internet access may be a useful tool in staying informed about current agricultural policy and regulations, as well as staying connected to a larger community, which may provide interaction and social support. Additionally, marketing through CSA's may improve feelings of social support, decrease stress for farmers, and contribute to human development at the local level. ${ }^{22}$

\section{Limitations}

To the authors' knowledge, this is the first study to use data from a large, national source to compare demographic characteristics of organic and non-organic producers in order to explore occupational safety and health issues. Manual transcription from USDA reports was conducted, which may have resulted in transcription error. Misclassification may have occurred because 
A comparative analysis of the organic and conventional producer

results are reported for both crop and livestock operations. We assumed that organic farmers in this analysis were not exposed to occupational hazards that affect non-organic POs, such as pesticides and chemicals. This may not be the case, since POs with any organic sales may also have non-organic sales. This study did not estimate risk, but rather explored personal and occupational factors that may play a role in injury and illness.

\section{Conclusion}

Sociodemographic characteristics and production practices differ between organic and nonorganic producers. This study makes a unique contribution to understanding the importance of collecting place-based surveillance data on organic farmers and exploring occupational safety and health factors faced by this population. Understanding and quantifying these differences is essential for occupational safety and health practice, allocation of resources, and policy development. 
A comparative analysis of the organic and conventional producer

\section{References}

1. Brigance, C., Soto Mas, F., Sanchez, V., \& Handal, A. J. (2018). The mental health of the organic farmer: Psychosocial and contextual actors. Workplace Health and Safety, 66(12), 606-616. doi: 10.1177/2165079918783211.

2. Soto Mas, F., Handal, A., Rohrer, R., \& Tomalá, E. (2018). Health and safety in organic farming: A qualitative study. Journal of Agromedicine, 23(1), 92-104. doi.org/10.1080/1059924X.2017.1382409.

3. NIOSH. (2020). Agricultural Safety. National Institutes for Occupational Safety and Health, Centers for Disease Control and Prevention. Page last reviewed: October 5. Retrieved from https://www.cdc.gov/niosh/topics/aginjury/default.html.

4. USDA. (2021). Growth in the number of certified organic operations continues in 2020. National Organic Program, Agricultural Marketing Service. Organic Insider Bulletin, 01/27. Retrieved from https://content.govdelivery.com/accounts/USDAAMS/bulletins/2ba210e

5. Colémont, A., \& Van den Broucke, S. (2006). Psychological determinants of behaviors leading to occupational injuries and diseases in agriculture: A literature overview. Journal of Agricultural Safety and Health, 12(3), 227-238. doi: 10.13031/2013.21230.

6. USDA. (2019). Farm Producers. Revised census questions provide expanded demographic information. 2017 Census of Agriculture. Highlights. ACH17-2/April. Retrieved from https://www.nass.usda.gov/Publications/Highlights/2019/2017Census_Farm_Producers.pdf.

7. US Department of Labor. (2016). Findings from the National Agricultural Workers Survey (NAWS) 2013-2014. A demographic and employment profile of United States farmworkers. Research Report No. 12. Retrieved from https://www.doleta.gov/naws/pages/research/docs/NAWS_Research_Report_12.pdf. 
A comparative analysis of the organic and conventional producer

8. Blair, A., Freeman, L. B. (2009). Epidemiologic studies in agricultural populations:

Observations and future directions. Journal of Agromedicine, 14(2):125-131. doi: 10.1080/10599240902779436.

9. Curl, C. L., Spivak, M., Phinney, R., \& Montrose, L. (2020). Synthetic Pesticides and Health in Vulnerable Populations: Agricultural Workers. Current Environmental Health Reports, 7(1), 13-29. doi: 10.1007/s40572-020-00266-5.

10. Bureau of Labor Statistics. (n.d.). Injuries, Illnesses, and Fatalities (IIF). US Department of Labor, BLS. Retrieved from https://www.bls.gov/iif/

11. US Department of Labor. (2019). The National Agricultural Workers Survey. Employment and Training Administration (ETA). Retrieved from https://www.doleta.gov/naws.

12. NIOSH. (2018a). Agricultural Safety. Occupational Injury Surveillance of Production Agriculture (OISPA). National Institutes for Occupational Safety and Health, Centers for Disease Control and Prevention. Page last reviewed: April 10 (archived document). Retrieved from https://www.cdc.gov/niosh/topics/aginjury/oispa/faq.html.

13. NIOSH. (2018b). Agricultural Safety-Farm Safety Survey (FSS). National Institutes of Occupational Safety and Health, Centers for Disease Control and Prevention. Page last reviewed: April 10 (archived document). Retrieved from https://www.cdc.gov/niosh/topics/aginjury/fss/default.html.

14. USDA. (2012). Census of Agriculture. National Agriculture Statistics Service. Retrieved from https://www.agcensus.usda.gov/Publications/2012/Online_Resources/Special_Organics_Tab ulation/organictab.pdf. 
A comparative analysis of the organic and conventional producer

15. Sinclair, R. C., Cunningham, T. R., \& Schulte, P. A. (2013). A model for occupational safety and health intervention diffusion to small businesses. American Journal of Industrial Medicine, 56(12), 1442-1451. doi: 10.1002/ajim.22263.

16. Sørensen, O. H., Hasle, P., \& Bach, E. (2007). Working in small enterprises: Is there a special risk? Safety Science, 45(10), 1044-1059. doi:10.1016/j.ssci.2006.09.005.

17. Pfortmueller, C. A., Kradolfer, D., Kunz M, Lehmann, B., Lindner, G., \& Exadaktylos, A. K. (2013). Injuries in agriculture: Injury severity and mortality. Swiss Medical Weekly, 143, w13846. doi:10.4414/smw.2013.13846.

18. Schulte, P. A., Pandalai, S., Wulsin, V., \& Chun, H. (2012). Interaction of occupational and personal risk factors in workforce health and safety. American Journal of Public Health, 102(3), 434-448. doi: 10.2105/AJPH.2011.300249.

19. Caffaro, F., Lundqvist, P., Cremasco, M., Nilsson, K., Pinzke, S., \& Cavallo, E. (2018). Machinery-related perceived risks and safety attitudes in senior Swedish farmers. Journal of Agromedicine, 23(1), 78-91. doi:10.1080/1059924X.2017.1384420.

20. McCoy, C., Carruth, A., \& Reed, D. (2002). Women in agriculture: Risks for occupational injury within the context of gendered role. Journal of Agricultural Safety and Health, 8(1), 37-50. doi: 10.13031/2013.7224.

21. Turgoose, C., Hall, L., Carter, A., Stride, C. (2006). Encouraging an increase in the employment of women returners in areas of skill shortage in traditionally male industries. Institute of Work Psychology. University of Sheffield, Sheffield, U.K.

22. Finley, L., Chappell, M. J., Thiers, P., \& Moore, J. R. (2018). Does organic farming present greater opportunities for employment and community development than conventional 
A comparative analysis of the organic and conventional producer

farming? A survey-based investigation in California and Washington. Agroecology and

Sustainable Food Systems, 42(5), 552-572. doi: 10.1080/21683565.2017.1394416 
A comparative analysis of the organic and conventional producer

Table 1. Farm Characteristics (NM)

\begin{tabular}{|c|c|c|c|}
\hline & $\begin{array}{l}\text { All Farms } \\
\mathrm{N}=\mathbf{2 4 , 7 2 1}\end{array}$ & $\begin{array}{c}\text { Farms With Any } \\
\text { Organic Sales } \\
N=153 \\
(0.6 \% \text { of all NM farms) }\end{array}$ & $\begin{array}{c}\text { Farms with No Organic } \\
\text { Sales } \\
\mathrm{N}=\mathbf{2 4 , 5 6 8} \\
(\mathbf{9 9 . 4 \%} \text { of all NM farms) }\end{array}$ \\
\hline & $\mathrm{N}\left(\%^{\mathrm{a}}\right)$ & $\mathrm{N}\left(\%^{\mathrm{a}}\right)$ & $\mathrm{N}\left(\%^{\mathrm{a}}\right)$ \\
\hline $\begin{array}{l}\text { Crop Farms (According } \\
\text { to NAICS Classification) }\end{array}$ & $16,176(65 \%)$ & $125(82 \%)$ & $16,051(65 \%)$ \\
\hline \multicolumn{4}{|l|}{ Size of Farm } \\
\hline 1-9 Acres & $7,861(32 \%)$ & $81(53 \%)$ & $7,780(32 \%)$ \\
\hline 10-499 Acres & $10,606(43 \%)$ & $64(42 \%)$ & $10,542(43 \%)$ \\
\hline$\geq 500$ Acres & $6,254(25 \%)$ & $8(5 \%)$ & $6,246(25 \%)$ \\
\hline $\begin{array}{l}\text { Average Total } \\
\text { Production Expenses per } \\
\text { Farm }\end{array}$ & $\$ 99,483$ & $\$ 86,445$ & $\$ 99,564$ \\
\hline $\begin{array}{l}\text { Average Total Sales per } \\
\text { Farm }\end{array}$ & $\$ 103,157$ & $\$ 85,275$ & $\$ 103,268$ \\
\hline $\begin{array}{l}\text { Farm is Family or } \\
\text { Individual-owned }\end{array}$ & $21,610(87 \%)$ & $115(75 \%)$ & $21,495(87 \%)$ \\
\hline $\begin{array}{l}\text { Average Number of } \\
\text { Workers Hired Per Farm }\end{array}$ & 4 & 3 & 4 \\
\hline Irrigated Land & $11,430(46 \%)$ & $147(96 \%)$ & $11,283(46 \%)$ \\
\hline $\begin{array}{l}\text { Farm had Renewable } \\
\text { Energy Producing } \\
\text { System }\end{array}$ & $1,279(5 \%)$ & $32(21 \%)$ & $1,247(5 \%)$ \\
\hline
\end{tabular}

a $\%=$ column percentage 
A comparative analysis of the organic and conventional producer

Table 2. Principal Operator Demographics (NM)

\begin{tabular}{|c|c|c|}
\hline Demographics & $\begin{array}{c}\text { Farms- Any } \\
\text { Organic Sales } \\
\mathrm{N}=153\end{array}$ & $\begin{array}{c}\text { Farms- No } \\
\text { Organic Sales } \\
\text { N=24,568 }\end{array}$ \\
\hline & $\mathrm{N}\left(\%^{\mathrm{a}}\right)$ & $\mathrm{N}\left(\%^{\mathrm{a}}\right)$ \\
\hline \multicolumn{3}{|l|}{ Sex } \\
\hline Male & $112(73 \%)$ & $19,832(81 \%)^{*}$ \\
\hline Female & $41(27 \%)$ & $4,736(19 \%)^{*}$ \\
\hline $\begin{array}{l}\text { Place of Residence: On Farm } \\
\text { Operated }\end{array}$ & $134(88 \%)$ & $18,018(73 \%)^{*}$ \\
\hline Spanish, Hispanic, or Latino Origin & $39(25 \%)$ & $9,338(38 \%)^{*}$ \\
\hline \multicolumn{3}{|l|}{ Race $^{\mathrm{b}}$} \\
\hline $\begin{array}{l}\text { American Indian or Alaska } \\
\text { Native }\end{array}$ & $0(0 \%)$ & $5,202(21 \%)^{* *}$ \\
\hline Asian & $0(0 \%)$ & $29(0 \%)$ \\
\hline Black or African American & $0(0 \%)$ & $39(0 \%)$ \\
\hline White & $153(100 \%)$ & $19,140(78 \%)^{* *}$ \\
\hline $\begin{array}{l}\text { Principal Operator is a Hired } \\
\text { Manager }\end{array}$ & $8(5 \%)$ & $1,038(4 \%)$ \\
\hline \multicolumn{3}{|l|}{ Number of People Living in Household } \\
\hline 1-2 people & $101(66 \%)$ & $16,272(66 \%)$ \\
\hline$>2$ people & $52(34 \%)$ & $8,296(34 \%)$ \\
\hline Primary Occupation: Farming & $91(59 \%)$ & $12,301(50 \%)^{*}$ \\
\hline \multicolumn{3}{|c|}{ Percent of Total Household Income Coming from Farming } \\
\hline$<25 \%$ & $94(61 \%)$ & $20,102(82 \%)^{* *}$ \\
\hline $25-100 \%$ & $59(39 \%)$ & $4,466(18 \%)^{* *}$ \\
\hline$<35$ Years Old & $18(12 \%)$ & $1,182(5 \%)^{*}$ \\
\hline 35-49 Years Old & $24(16 \%)$ & $3,680(15 \%)$ \\
\hline 50-69 Years Old & $92(60 \%)$ & $12,998(53 \%)$ \\
\hline 70+ Years Old & $19(12 \%)$ & $6,708(27 \%)^{* *}$ \\
\hline $\begin{array}{l}\text { Average Age of Principal Operator } \\
\text { (Yrs. } \pm \text { S.D.) }\end{array}$ & $55.8 \pm 9.5$ & $60.5 \pm 5.5^{* *}$ \\
\hline \multicolumn{3}{|l|}{ Years Operating Any Farm } \\
\hline$\leq 4$ years & $23(15 \%)$ & $1,671(7 \%)^{*}$ \\
\hline 5-9 years & $29(19 \%)$ & $2,739(11 \%)^{*}$ \\
\hline$\geq 10$ years & $101(66 \%)$ & $20,158(82 \%)^{* *}$ \\
\hline $\begin{array}{l}\text { Average Years Operating Any Farm } \\
\text { (Yrs. } \pm \text { S.D.) }\end{array}$ & $19.5 \pm 6.8$ & $25.2 \pm 6.8^{* *}$ \\
\hline
\end{tabular}

a $\%=$ column percentage

${ }^{\mathrm{b}}$ this table does not include all of the race categories reported in the 2012 USDA COA

*significantly different when compared to NM farms with any organic sales at the $\mathrm{p}<0.05$ level

**significantly different when compared to NM farms with any organic sales at the $\mathrm{p}<0.0001$ level 
A comparative analysis of the organic and conventional producer

Table 3. Farming Production Practices (NM)

\begin{tabular}{|l|c|c|}
\hline \multicolumn{1}{|c|}{$\begin{array}{c}\text { Production } \\
\text { Practices }\end{array}$} & $\begin{array}{c}\text { Farms- Any } \\
\text { Organic Sales } \\
\mathbf{N = 1 5 3}\end{array}$ & $\begin{array}{c}\text { Farms- No Organic } \\
\text { Sales } \\
\mathbf{N}=\mathbf{2 4 , 5 6 8}\end{array}$ \\
\hline $\begin{array}{l}\text { Farm Production } \\
\text { Expenses: Average } \\
\text { per Farm }\end{array}$ & $\$ 86,445$ & $\mathrm{~N}\left(\%^{\mathrm{a}}\right)$ \\
\hline $\begin{array}{l}\text { Land Enrolled in } \\
\text { Crop Insurance } \\
\text { Programs }\end{array}$ & $10(6.5 \%)$ & $1447(5.9 \%)$ \\
\hline $\begin{array}{l}\text { Cropland on Which } \\
\text { Conventional }\end{array}$ & $53(34.6 \%)$ & $2,806(11.4 \%)^{* *}$ \\
$\begin{array}{l}\text { Tillage Practices } \\
\text { Were Used }\end{array}$ & $18(11.8 \%)$ & $1,293(5.3 \%)^{*}$ \\
\hline $\begin{array}{l}\text { Cropland on Which } \\
\text { No-Till Practices } \\
\text { Were Used }\end{array}$ & $141(92.2 \%)$ & $13,655(55.6 \%)^{* *}$ \\
\hline $\begin{array}{l}\text { Farm Had Internet } \\
\text { Access }\end{array}$ & $23(15.0 \%)$ & $173(0.7 \%)^{* *}$ \\
\hline $\begin{array}{l}\text { Farm Marketed } \\
\text { Products Through } \\
\text { Community } \\
\begin{array}{l}\text { Supported } \\
\text { Agriculture (CSA) }\end{array}\end{array}$ & & \\
\hline
\end{tabular}

a $\%=$ column percentage

*significantly different when compared to NM farms with any organic sales at the $\mathrm{p}<0.05$ level

**significantly different when compared to NM farms with any organic sales at the $\mathrm{p}<0.0001$ level 